\title{
Ecological Bio Energy Materials in Ukraine Current State and Prospects of Production Development
}

\author{
V. M. Sinchenko¹, V. S. Bondar ${ }^{1}$, M. Ya. Gumentyk ${ }^{1}$, Yu. A. Pastukh ${ }^{2}$ \\ ${ }^{1}$ Institute of Bioenergy Crops and Sugar Beet of NAAS, 25 Klinichna St., Kyiv, 03141, Ukraine \\ ${ }^{2}$ State agrarian and engineering university in Podilya, 13 Shevchenko St., Kamianets-Podilskyi, 32316, \\ Ukraine
}

E-mail: hmy@ukr.net; zatniva@gmail.com

Received 16.01.2020, Accepted 07.02.2020

\begin{abstract}
The article presents the results of the analysis of the state of bioenergy in Ukraine in recent years, and notes a significant gap between its development indicators and those of other countries in the world. Measures for accelerated rates of biofuel production for the period up to 2025 and its projected indicators are substantiated. In particular, total biofuel production in Ukraine should increase from 2.83 million to 6.2 million tons, including: solid types up to -3.5 million tons BOE, liquid-up to 0.7 million tons BOE, biogas-up to 2.0 million tons BOE. The list of main types of raw materials for biofuel production is given. The economic, technological, and economic characteristics of the main bioenergy crops, plantations of which are recommended to be laid in the coming years, are given. These performance indicators are obtained in production experiments, especially the ability to absorb carbon dioxide from the atmosphere and release oxygen, as well as reduce emissions of harmful substances during combustion. It is established that such a crop as Paulownia is the fastest growing plant (5-6 m per year). Another advantage of Paulownia is the high degree of environmental friendliness. One hectare consumes 1200 tons of $\mathrm{CO}_{2}$, significantly improving degraded, marginal land. The recommendations for the creation of industrial plantations of bioenergy crops and the material and technical base for processing are substantiated. Total costs for bioenergy by 2025 in the amount of $\$ 1,379$ million have been determined. Proposal for co-operation of producers and processors of bio-raw materials at the local level is suggested.
\end{abstract}

Keywords: Bioenergy; Ecology; Biomass; Biofuels; Bioenergy plants; Energy plantations; Fast growing crops; Marginal lands

\section{Introduction}

Ukraine, with considerable potential for bioenergy development, still lags far behind the rest of the world, especially Europe. Some countries have already achieved the substitution of $40 \%$ of fossil fuels for biological fuels, while Ukraine produces only $3.5 \%$ of total energy consumed. Some renewed interest in the use of biofuels in the last 2-3 years, availability of bulk raw materials base, increase in demand and prices for biological fuels make it possible for Ukraine to double the achieved level of biofuels production and bring it up to 6.2 million tons of oil equivalent in 2025, and in the longer term -up to 12 million tons To do this, one needs to expand the logistics base of the industry, and invest \$1379 million (Bondar \& Fursa 2015). One of the reserves of increasing biofuel production in Ukraine is not only the efficient use of existing agricultural and forestry wastes, but also the creation of special plantations of bioenergy crops on marginal lands, such as energy willow, miscanthus, Jerusalem artichoke, sida, millet, etc. Special attention should be paid to the cultivation of new environmentally friendly, highly productive crops, among which the most valuable and versatile is Paulownia. It is not only a fast-growing (5-6 m per year), but also a long-growing (up to 50 years) plant, with a productivity of $0.6-0.8 \mathrm{~m}^{3}$ of wood per tree for a five-year cycle with an amount of $625 \mathrm{pcs} / \mathrm{ha}$, with a calorific value capacity of 4.67 $\mathrm{kcal} / \mathrm{kg}$, or $18.5 \mathrm{~J} / \mathrm{kg}$. This culture is also a good honey plant and building material. But the biggest advantage of the plant is its environmental friendliness. A 1 ha plantation of Paulownia absorbs 1,200 tons of $\mathrm{CO}_{2}$ per year, significantly improving degraded, marginal soils, and produces virtually clean emissions when burned. Other crops that can produce a fairly high amount of wood biomass used for solid biofuels are: poplars, Bosnian maple, sugar maple, for liquid and gaseous fuels: sugar beets, sugar sorghum, corn, and pilotweed. The productivity, technological characteristics and energy intensity of the main crops are summarized in the relevant tables, graphs, and figures.

\section{Problem statement}

Ukraine is still an energy dependent state, which only partially supplies itself with energy resources and is forced to import annually a large part of fossil energy such as natural gas, petroleum products, coal, whose prices increase as production volumes decrease. However, the use of renewable energy sources, which Ukraine is rich in, has been low for a long period. In 2012, natural gas replacement by biofuels amounted to 1.1 billion $\mathrm{m}^{3}$, in $2018-3.5$ billion $\mathrm{m}^{3}$, or $3.3 \%$ of final energy consumption. At the same time, the share of bioenergy in the overall structure of global energy consumption is $14 \%$, and in some Scandinavian countries it is 17 $40 \%$, which creates good prospects for its development. There are also all prerequisites for this in Ukraine. It is rich in bioenergy resources such as wood biomass, agricultural waste -straw, corn stalks and cores, sunflower husks, sugar beet pulp and molasses, corn silage, livestock and poultry manure, sewage waters and water sources. At the same time, there are large areas of lowproductive and "marginal" lands in Ukraine, on which it is possible to obtain large volumes of biomass of highly productive energy crops: willow, poplar, paulownia, miscanthus, millet, sorghum sugar, etc. The total biomass potential available for bioenergy is 
89950 thousand tons, but only 10466 thousand tons is used, or $11.6 \%$. Biogas production potential in Ukraine based on specially grown bioenergy crops and organic waste can reach 20 billion $\mathrm{m}^{3}$ per year (Bondar et al., 2018). The purpose of the article is analysis of the current state and prospects of development of bioenergy in Ukraine for the period up to 2025; characterization of the most valuable ecological, technological, economic and productive qualities of new bioenergy crops as raw materials for bioenergy, and proposals for laying industrial plantations of such crops and creation of material and technical base of bioenergy as a whole.

\section{Research Methodology}

The research used the following methods: monographic, systematic analysis of dynamics series, design and construction, graphical, expert assessments, known methods and techniques of processing and analysis of computer information, as well as a number of field research methods with subsequent statistical processing of the obtained results. Biometric indicators, yield of green mass and grain were determined by conventional methods. Plant height was measured using a measuring ruler, the diameter of the plant stem using a caliper. Data processing was performed using the software package provided with the equipment. As a criterion for evaluating the thermal stability of biomass, the activation energy of thermo-oxidative degradation was determined using Broido's double logarithmization method (Broido, 1969; Prokopchuk, 1983). All the results obtained were processed by statistical methods using the StatGraphics Plus-5 computer software package.

Elements of scientific novelty. Priorities have been identified and specific indicators for the development of raw materials and processing base of bioenergy in Ukraine for the period up to 2025 have been determined, economic and environmental substantiation of the need for the use of new high-yielding, environmentally friendly crops for use in bioenergy has been made, in particular, certain varieties of paulownia culture were introduced taking into account the soil and climatic conditions of Ukraine Practical importance. The results of the research can be used by state and local authorities in planning and forecasting environmental programs, bioenergy development strategies in the regions, and by farmers to create high-yield bioenergy plantations, including paulownia and its processing for biofuel at the local level.

Analysis of recent publications. Bioenergy issues are primarily dealt with by the Institute of Economics and Forecasting of the National Academy of Sciences of Ukraine, the Institute of Bioenergy Crops and Sugar Beet, NAAS, the Institute of Food Resources of NAAS, the Bioenergy Association of Ukraine and other institutions and organizations. The Institute of Bioenergy Crops, in particular, has introduced a number of bioenergy crops such as miscanthus, rod millet, sugar sorghum, energy willow, poplar, paulownia, etc. raised domestic varieties of these crops, created research plantations, substantiated cultivation and harvesting technologies. Significant contribution to the development of bioenergy are made by candidate of technical sciences $\mathrm{H}$. Heletukha; T. Zhelezna (Heletukha H.H., et al., 2018, 2016, Diachuk O. et al., 2017) especially with relation to technical, technological, and organizational issues and problems. However, as a whole, along with the coverage in the scientific literature of certain advances in technology of production of bio-raw materials of potential capabilities of certain crops and types of fuel, the calculations of the cost of their processing and use, profitability indicators, payback periods of bioenergy objects, etc. are insufficiently performed.

The last 3-4 years in Ukraine in the field of bioenergy have seen a significant recovery. In particular, a number of European level bioenergy projects, especially related to biogas, have been carried out, including Astarta, Goodwell Ukraine, Ekoprod, Rakitne, Slavuta, Niva, Dniprovska, Gnidavskyi Sugar Refinery and others. Large agricultural company Myronivskyi Khliboproduct is building a large 20 MW biogas complex near Ladyzhyn (Vinnytsia region) (Heletukha H. et al., 2018)

Nevertheless, there are still many unresolved and complex problems in Ukrainian bioenergy engineering. Today, there is practically no clear state-level bioenergy development strategy related to the development of bioenergy structures, especially at the level of associations of territorial communities of cities, towns, and villages. The country is experiencing strong opposition from leading energy companies and their lobby against the use of biological fuels, especially bioethanol and biogas, which are dangerous for them. There is an insufficient amount of public and private investment in bioenergy, especially in the scientific and technical sphere. There are certain barriers for biofuels producers and intransparent rules imposed on them. Also, tariffs for bio-energy raw materials, prices and conditions for connection to the transmission and distribution systems of heat and electricity, etc. are not clearly worked out. The most significant drawback is the large gap between the promotion of bioenergy, the potential of bioenergy crops and fuels, and the actual implementation of these measures. The economic problems of bioenergy remain virtually unresolved. In particular, the creation of a material and technical base that would significantly increase the share of renewable energy sources in the overall energy balance, which would not only strengthen the energy independence of our country but also reduce greenhouse gas emissions and slow down global climate change processes.

\section{Results}

It is known that one of the reasons for climate change is the increase in the Earth's atmosphere of the concentration of greenhouse gases, especially carbon dioxide and methane, so the use of bioenergy crops to produce biofuels, their ability to absorb carbon dioxide from the atmosphere and release oxygen must be taken into account. Carbon dioxide is most intensively absorbed and oxygen is produced by such highly productive C4 bioenergy crops such as paulownia, sugar sorghum, sugar beet, and corn. For example, during the growing season, sugar sorghum, plants hourly absorb $9.2 \mathrm{~m}^{3}$ of carbon dioxide and emit $4.8 \mathrm{~m}^{3}$ of oxygen per hectare of plantation. Maximum values are reached by the new energy plant - paulownia, whose leaves absorb $15.0 \mathrm{~m}^{3}$ of $\mathrm{CO}_{2}$ and produce $6.0 \mathrm{~m}^{3}$ of oxygen (Figure 1). At the same time, the bioenergy sector of Ukraine requires considerable material costs, investments, and innovations. It is established that by its natural potential, Ukraine is capable of producing up to 50 million tons of conventional fuel (c.f.) per year. The economically justified level is estimated by experts at 20-25 million tons. However, the underdevelopment of the bioenergy material and technical base, the low rate of increase in the share of electricity produced from renewable sources, is the reason why the share of RES in total electricity production increased from 0.43 to 1.47 in the period from 2012 to $2017 . \%$ and amounted to $1374,712 \mathrm{GW}$ against $93517,823 \mathrm{GW}$, with a biomass share of $80 \%$. This means that bioenergy is still the leading link in the RES circuit compared to wind, solar and hydropower (Ihnatenko O, 2016; Kaletnik H, 2013, Pashover A., 2018). 


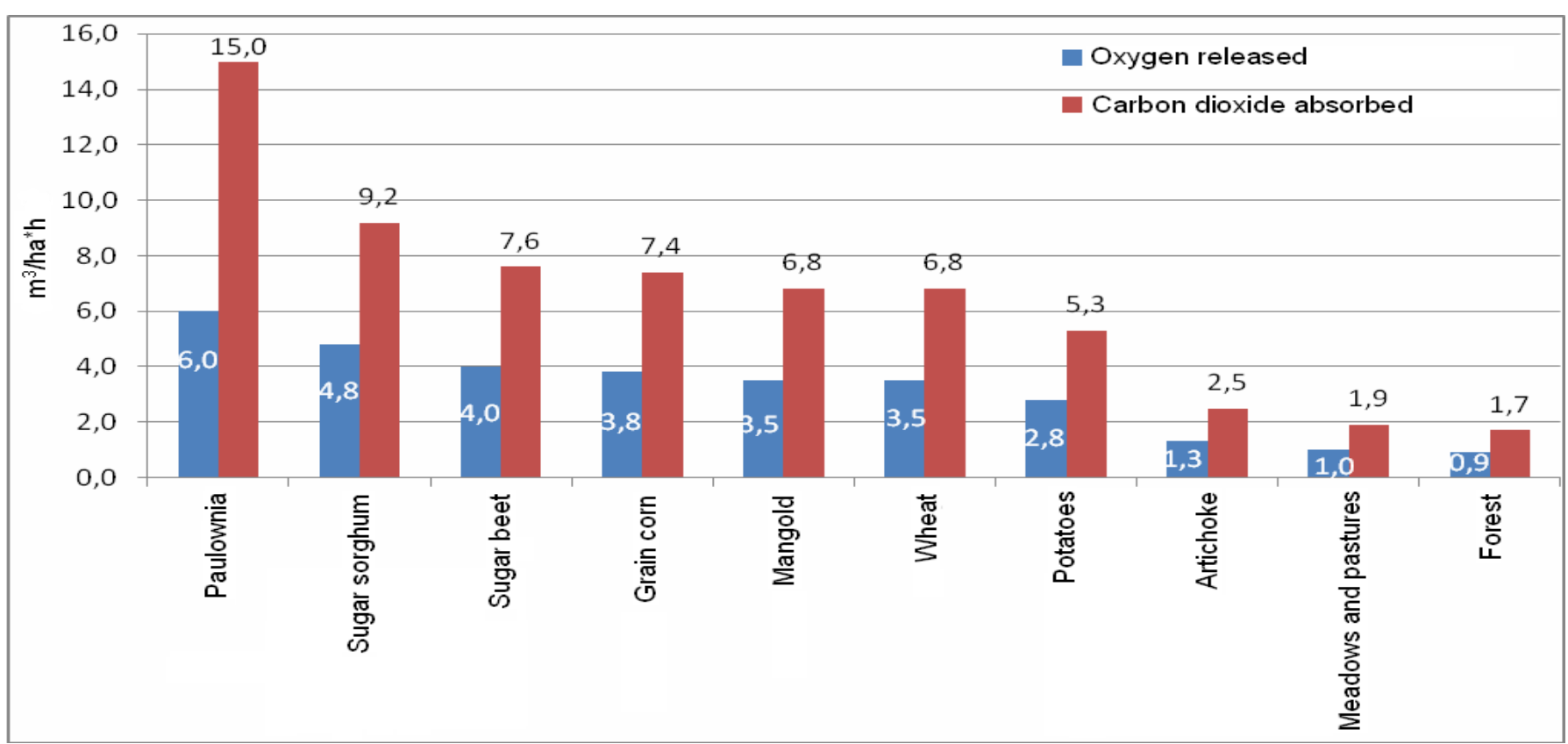

Figure 1. Carbondioxide uptake and oxygen release by certain high-performance bioenergy crops.

The main advantages of plant biomass as a source of alternative energy are the environmental purity of emissions compared to fossil fuels and the absence of a negative effect on the carbon dioxide balance in the atmosphere. During the combustion of biofuels based on plant biomass, less carbon dioxide is released into the atmosphere than is absorbed by plants in the process of photosynthesis, it produces $20 \ldots 30$ times less sulfur oxide and $3 \ldots 4$ times less ash compared to coal. A by-product of the combustion of solid biofuels is an organic substance that can be used as a fertilizer. (Giampietro M., \& Ulgiati S. 2005) The cultivation of bioenergy crops, the production and use of biofuels creates additional employment for the rural population and is a source of income, particularly in rural areas where there is a severe shortage of jobs. Considering the agrarian orientation of the country's economy and favorable soil and climate conditions for growing plants, bioenergy should become the most promising energy segment for Ukraine. Currently in Ukraine there are about two hundred enterprises for the production of fuel pellets, thousands of small, medium and large boilers operating on wood waste, firewood, chips, granules, more than 200 boilers and generators for bale straw, sunflower husks, corn stalks and other biomass. For biogas, corn silage (green), sugar beet pulp, livestock cattle manure, poultry manure, etc. are used. Plantations of energy willow (more than 5 thousand hectares), miscanthus (about 2 thousand hectares) and other cultures are laid out. Some sugar refineries produce molasses bioethanol, as well as organic solvents, feed additives, organic bard fertilizers, microbiological preparations, and other products. However, due to the difficult economic situation of Ukraine caused by both internal and external problems, it is impossible to achieve maximum development of bioenergy crops. Therefore, the real forecast for the development of bioenergy in Ukraine for the period 2018-2025 is recognized as follows (Table 1).

Table 1. Status and forecast of the structure of bioenergy development in Ukraine in 2018-2025, million tons.

\begin{tabular}{lllll}
\hline Types of fuel & \multicolumn{2}{c}{$\mathbf{2 0 1 8 , \text { current state }}$} & $\mathbf{2 0 2 5}$ forcast & \\
& mln tons, BOE & $\mathbf{\%}$ & min tons, BOE & \% \\
Solid & 2,07 & 73,2 & 3,5 & 56,5 \\
Liquid & 0,27 & 9,5 & 0,7 & 11,3 \\
Biogas & 0,49 & 17,3 & 2,0 & 32,2 \\
Total & 2,83 & 100 & 6,2 & 100 \\
\hline
\end{tabular}

Not only trends of biotechnology developed in previous years, but also real positive changes for the 2012-2018 period, as well as strategic challenges and problems that have been taken into account in determining the volume of biofuel production for the future as a whole and in terms of individual species, are facing the bioenergy industry for years to come. Thus, the total supply of primary energy for a number of objective and subjective reasons in Ukraine decreased from 2007 to 2017 by $35.7 \%$ from 139.3 million to 89.6 million tons. The structure of imports has changed. If the purchase of coal in recent years increased by $46 \%$ and oil products by $18 \%$, imports of crude oil have been virtually halted, and the volume of natural gas purchases has been significantly (almost $72 \%$ ) reduced. At the same time, Ukraine reduced its energy exports by 1.4 million tons, which is $27.4 \%$ of 2014 volumes. The total energy production, which in 2017 amounted to 58.8 million tons, decreased significantly, consumption was in the range of 50 million tons (WBA Global Bioenergy Statistics, 2017, Ukraine's Energy Balance, 2018). In these circumstances, the role of bioenergy is greatly enhanced, at the same time the pace of its development and internal contradictions are such that neither the state nor civil society can yet satisfy. The main problems that need to be addressed immediately are the updating of the state development strategy of this sector for the medium (20 years) and long-term perspective (50 years); determine priorities for the production of certain types of biofuels and make calculations for the creation of a suitable material and technical base - determine the types and quantities of bioenergy complexes, their cost and payback period and financial support. Bioenergy engineering can become, if not the main one, the decisive factor of energy independence and security of the state in the conditions of harsh competition. 
The use of forest resources at this stage in Ukraine for the production of solid biofuels is unacceptable, as the average afforestation of the territory of Ukraine is $15.6 \%$, which is one of the lowest among European countries. For the successful development of bioenergy it is necessary to create special energy plantations and forest protection strips on the basis of highly productive bioenergy crops (energy willow, poplar, paulownia and others) for the production of wood, biofuels, prevention of environmental pollution and desertification of the territories of Ukraine. To create special energy plantations of woody plants it is necessary to use primarily the representatives of willow-poplar family, paulownia as the fastest growing trees and shrubs. In the southern regions of Ukraine white acacia, ash maple and other species can be used.

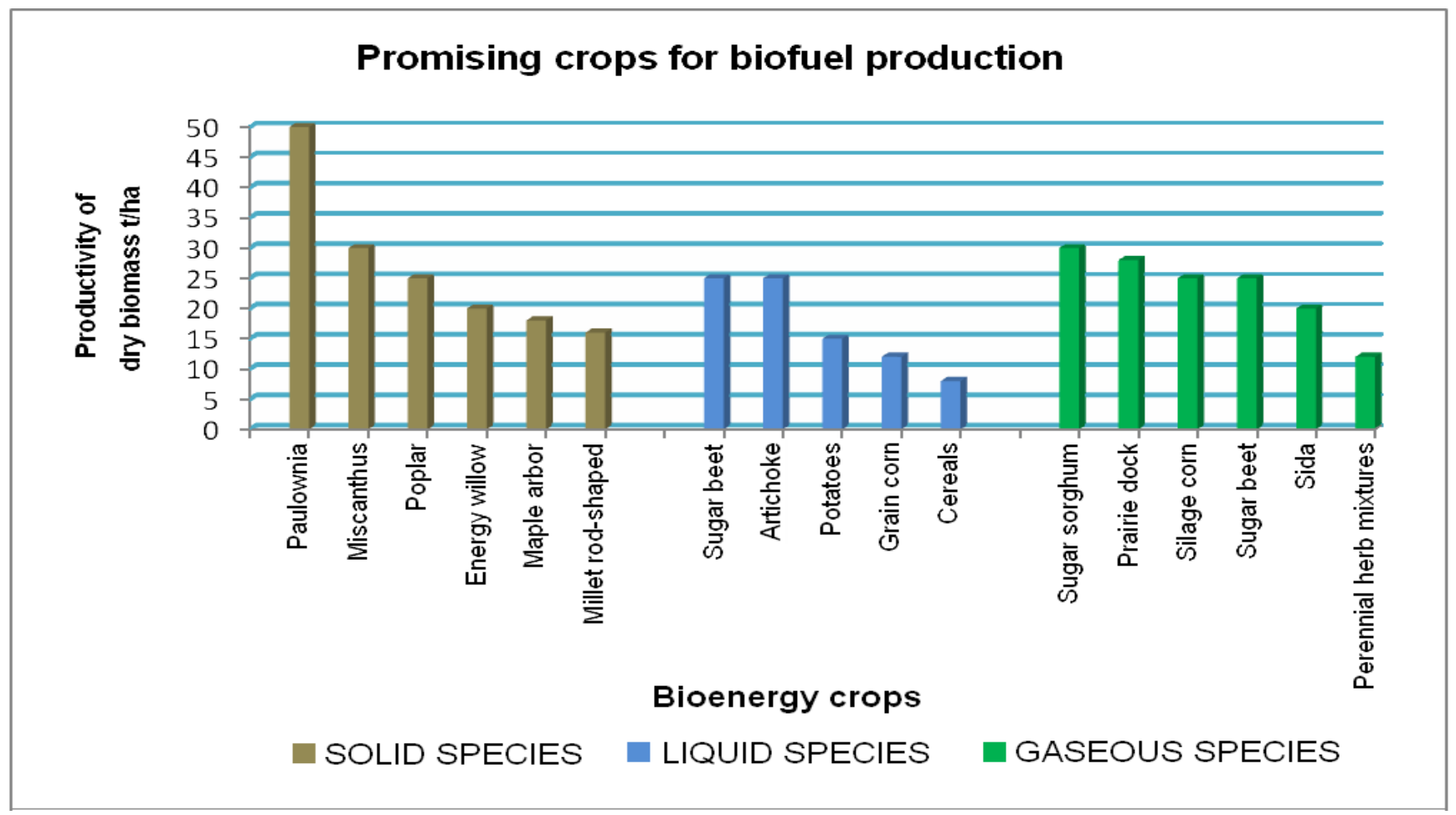

Figure 2. Productivity of bioenergy crops, whose raw materials are used for the production of solid, liquid, and gaseous fuels.

The technology of cultivating fast-growing high-yielding woody plants allows to obtain high-quality wood and a considerable amount of biomass for the production of biofuels in the short term, preserve trees that will reproduce new biomass in 3-5 years. Among the wide range of bioenergy crops that researchers from the Institute of Bioenergy Crops and Sugar Beet are investigating, new, promising and economically viable for the production of solid biofuels, namely, wood chips, pellets, briquettes, such woody crops as poplar and paulownia have been identified, among cereals: miscanthus and millet (Figure 2). Due to their environmental characteristics, they can form the basis of energy plantations as a means of combating global warming. Paulownia in the world practice is mainly used in the construction industry and is a valuable energy raw material in bioenergy. For this purpose, all parts of the tree are used: trunk, branches, and leaves. Paulownia biomass is also used as raw material for the production of bioethanol. Scientists have developed a technology based on a combination of thermochemical and biotechnological methods, which can produce about 500 liters of ethanol from one ton of dry Paulownia wood. Paulownia plants are regenerated from their own root system and can grow again up to four to five times after the first felling. The stem roots of Paulownia reach $9 \mathrm{~m}$ deep, where they get the nutrients from, so that other plants can freely coexist with them. Due to their deep roots, they do not deplete the topsoil required for the growth of other plants.

Compared to other tree species, Paulownia wood is lighter (its density is $300-350 \mathrm{~kg} / \mathrm{m}^{3}$ when dried outdoors), Paulownia biomass (wood) is lit only at high temperatures $\left(420-430^{\circ} \mathrm{C}\right)$, its calorific value is $4,669.5 \mathrm{kcal} . / \mathrm{kg}(18,520 \mathrm{~J} / \mathrm{kg})$ at a humidity of $40 \%$. It retains heat well and dries quickly (24-28 hours in the dryer and 30-60 days outdoors). The wood is very soft but not deformed. Compared to metals, Paulownia between the trees corresponds to aluminum among the metals. The weight of $1 \mathrm{~m}^{3}$ of tree is about $290-310 \mathrm{~kg}$, and the roundwood costs about $100-120 € / \mathrm{m}$, on the outside it is similar to ash tree.

Paulownia can reach $27 \mathrm{~m}$ in height and from 0.3 to $1 \mathrm{~m}$ in diameter. The leaves of Paulownia are rich in nitrogen, providing nutrients after falling and rotting on the ground. Plants can grow on poor or eroded soils. Biomass can be harvested every $3-5$ years, repeated planting is not needed.

The tree trunk grows approximately 5-6 meters a year without knots and knurls. Ecologists have recognized paulownia as the largest absorber of carbon dioxide, resulting in the maximum amount of oxygen in the air during photosynthesis. There are approximately 600 trees on each hectare of Paulownia energy plantation, which annually absorb 1,200 tons of carbon dioxide. This tree is capable of improving degraded soil, and it also absorbs up to ten more $\mathrm{CO}_{2}$ than any other species. Paulownia leaf mass is very often used to feed herbivorous animals (cows, sheep, goats, etc.). Moreover, its nutritional characteristics are close to alfalfa and clover, especially in the content in the green mass of up to $20 \%$ of proteins and the complex of trace elements. The leaves of the culture reach up to $75-80 \mathrm{~cm}$ in diameter.

The leaf surface of one paulownia tree absorbs an average of 15-20 kg of carbon dioxide, producing $6 \mathrm{~kg}$ of oxygen in one hour. Thus, thousands of cubic meters of air are cleaned, which is of great ecological importance in the densely populated areas of Ukraine. An important environmental and economic aspect of the development of the bioenergy industry is the creation of its own raw material base, through the laying of special energy plantations and forest protection strips based on highly productive tree crops, whose biomass can be used as a raw material for biofuel production. The list of such species of trees, along with poplar, willow and paulownia, include Bosnian maple, sugar maple, Tatar maple, and green ash. Among the fast-growing breeds birch, 
white acacia, Canadian poplar and other poplars, small-leaved elm, honey-locust and maple can be used. Certain types of trees for planting in forest strips are selected taking into account local soil and climatic conditions. An important environmental and economic aspect of the development of the bioenergy industry may be the creation of a raw material base at the local level in villages, settlements, small towns in the form of energy farms in order to meet their own needs for fuel and sell thermal energy to other consumers in terms of obtaining heat energy. For the successful development of bioenergy and increased profitability of the biofuels industry in Ukraine, cooperation of two directions of the industry, production of raw materials and final products in the form of energy is required. Formation of cooperation between biomass producers and fuel and energy enterprises will reduce the cost of obtaining energy produced from vegetable raw materials.

\section{Conclusion}

1. Ukraine has all the necessary prerequisites for accelerated development of a new branch of the economy - bioenergy, regulatory, scientific, technical and financial support for its successful functioning.

2. In order to improve the environmental situation, increase the use of renewable energy sources in Ukraine, it is necessary to increase the area covered by energy plantations of special high-performance bioenergy crops.

3. To provide raw materials for biofuels and heat-generating facilities in the country's housing and communal services, the most promising bioenergy crops for the production of solid biofuels are paulownia, poplar and miscanthus; sugar sorghum and selfpollinator for gaseous varieties.

4. In order to stimulate the development of bioenergy at the national level, introduce a preferential system of taxation for energy farms for the first 5 years and develop a system of interest-free bank lending for the purchase of machinery and equipment to plant high-yielding bioenergy crops and care for the cultivation and harvesting of their biomass.

\section{References}

Bondar V.S., Fursa A.V. \& Humentyk M.Ya. (2018). Bioenergy development strategy and priorities in Ukraine. Ekonomika APK. No 3. 17-25 (in Ukrainian)

Bondar V.S., \& Fursa A.V. (2015). Ekonomichne obgruntuvannia tekhnolohii vyroshchuvannia i pererobky roslynnoi biosyrovyny na tverdi vydy palyva. Ekonomika APK. No 3. 22-27 (in Ukrainian)

Broido A. (1969). A simple, sensitive graphical method of treating thermogravimetric analysis data. J. Polymer of Science. Vol. 7. No. 3. P. 1761-1763. https://doi.org/10.1002/pol.1969.160071012 (In USA

Diachuk O., Chepeliev M., Pomolets R., Trypolska H., Venher V., Saprykina T., \& Yukhymets R. (2017). Perekhid Ukrainy na vidnovliuvalnu enerhetyku do 2050 roku: zvit za rezultatamy modeliuvannia bazovoho ta alternatyvnykh stsenariiv rozvytku bioenerhetychnoho sektoru / za zah. red. Yu. Oharenko ta O. Aliievoi. Kyiv: TOV «ART KNYHA» (in Ukrainian)

Prokopchuk N. R. (1983). Determination of activation energy of polymer degradation according to thermogravimetry. Plastics. No 10. C. 24-25 (in Russian)

Heletukha H.H., Zheliezna T.A., Kramar V.H., \& Kucheruk P.P. (2018). Perspektyvy rozvytku bioenerhetyky yak instrumentu zamishchennia pryrodnoho hazu v Ukraini. Bioenerhetychna asotsiatsiia Ukrainy, $2015 . \quad$ URL: http://uabio.org/img/files/docs/position-paper-uabio-12-ua.pdf (data zvernennia: 02 lypnia 2018). (in Ukrainian)

Heletukha H., Oliinyk Ye., Antonechko V., Chaplyhin S., Hubenko V., \& Radchenko S. (2016). Provedennia kompleksnoho doslidzhennia rynku kotliv, shcho pratsiuiut na biomasi v Ukraini. Kyiv: Prohrama rozvytku Orhanizatsii Ob'iednanykh Natsii. (in Ukrainian)

Heletukha H.H., Zheliezna T.A., Kucheruk P.P.,\& Oliinyk Ye.M. Suchasnyi. (2018). Stan ta perspektyvy rozvytku bioenerhetyky v Ukraini. http://www.uabio.org/img/files/docs/position-paper-uabio-9-ua.pdf (data zvernennia: 19 chervnia 2018). (in Ukrainian)

Ihnatenko, O.P. (2016). Vykorystannia biomasy u munitsypalnomu sektori: praktychnyi posibnyk. Proekt PROON/HEF «Rozvytok ta komertsializatsiia bioenerhetychnykh tekhnolohii u munitsypalnomu sektori Ukrainy». Kyiv (in Ukrainian)

Kaletnik, H.M. (2013). Rozvytok rynku biopalyv v Ukraini. Bioenerhetyka. No 1. 11-16 (in Ukrainian)

Pashover, A. (2018). Gorjuchee predlozhenie. Novoe vremja stran No 7. (22 fev.) 34-37 (in Ukrainian)

Enerhetychnyi balans Ukrainy, (2018). URL http://www.ukrstat.gov.ua/ (data zvernennia: 14 chervnia 2018) (in Ukrainian)

Vidnovliuvana enerhetyka v Ukraini: sohodennia ta perspektyvy. Ukrainska asotsiatsiia vidnovliuvanoi enerhetyky. URL: https://vse.energy/docs/OEW-orgel.pdf (data zvernennia: 02 lypnia 2018) (in Ukrainian)

Giampietro M., \& Ulgiati S. (2005). Integrated Assessment of Large-Scale Biofuel Production. Critical Reviewsin Plant Sciences. URL: https://doi.org/10.1080/07352680500316300 (data zvernennia: 14 chervnia 2018) (in Brazil)

WBA Global Bioenergy Statistics, (2017). URL: https://worldbioenergy.org/uploads/ WBA\%20GBS\%202017_hq.pdf (data zvernennia: 02 lypnia 2018). (in Belgium)

\section{Citation:}

Sinchenko, V. M., Bondar, V. S., Gumentyk, M. Ya., Pastukh, Yu. A. (2020). Ecological Bio Energy Materials in Ukraine Current State and Prospects of Production Development. Ukrainian Journal of Ecology, 10(1), 85-89.

\begin{tabular}{|l|l}
\hline$(\mathrm{cc}) \mathrm{EY}$ \\
$\mathrm{Br}$
\end{tabular} 